\title{
The idea of zoopolis in contemporary architectural dimension
}

\author{
Justyna Kleszcz ${ }^{1, *}$ \\ ${ }^{1}$ Department of Architecture and Urban Planning, Faculty of Civil Engineering, Architecture and \\ Environmental Engineering, University of Zielona Góra, ul. Szafrana 1, 65-516 Zielona Góra, \\ Poland
}

\begin{abstract}
In recent times, the idea of non-anthropocentric architecture has become one of the determinants of contemporary, conscious approach towards design as a process. Its characteristic feature is the extension of both, recognized as "urban" functions, as well as the group of recipients on which the created space is to interact. The direct connection between the notion of a city created by people (polis) and the animal world (zoo) was a long-lasting, multi-faceted process of broadening the meaning of animal subjectivity in culture, art and politics. The very concept of zoopolis, appearing for the first time in the work of Donaldson and Kymlicka in 2011, was initially applied to political science, in the context of places shared by man and domestic animals, where the city was understood as a political community of its inhabitants, including non-humans. In the sphere of creating physical space, this concept appeared for the first time two years later thanks to Jennifer Wolch. In terms of zoopolis, the urbanized space will be a set of parallel worlds in which both people and nature live in the same area, whose multiple layers only sometimes cross or overlap. The purpose of the work is to allow tracing the main determinants of the transformation process of contemporary policy from small point elements to systemic actions and identify the main features of a non-anthropocentric city as a place for the emergence of new functions and urban forms.
\end{abstract}

\section{Biology, philosophy, urbanization crisis - about the factors forming contemporary cities}

The crisis of urbanity, manifested primarily by the rapid increase of the world urbanization and exceeding the level of $54 \%$ in 2014 , has resulted in recent decades of rapid search for new urban forms to become an alternative to what the city has become today. The global trend indicates that by 2050 more than $66 \%$ of the world's population will live in urbanized areas [1], and the size of areas with urbanization of up to $100 \%$ will continue to grow and come out of the group of mega-cities as before. Therefore, the search for an alternative to the city as a form, but also as a method of social development will deepen and widen in the near future.

\footnotetext{
*Corresponding author: j.kleszcz@aiu.uz.zgora.pl
} 
This research recently focused on issues related either to the adaptation of existing urban structures to the growing population or to the search for alternative solutions for newly created structures. In both of these groups, an increasingly important element of the solution is the need to include various forms of nature in the city structure, related to both increasing level of mixing city and nature, as well as the need to maintain a linkage between man and natural environment in order to save the planet as such.

The city and ecology, urbanization with zero ecological footprint, but also a city that is able to feed itself are the most vital issues in the latest practical and theoretical research. The connection of the city and biology concepts, including the idea of biomes brought to life more than 30 years ago, gave rise to the theory of the urban biome. The concept of biome refers explicitly to the field of natural sciences, on the other hand, since the mid-1980s, it has been functioning in the theory of urban and spatial planning as an urban biome, whose meaning was formulated by Lech Zimowski [2].

The taxonomic division of the world of nature is defined by the biome itself, as a set of biocenoses, which in a specified climatic zone create a climax stage, i.e. a certain permanent natural form, depending either on the location in a climatic zone or on soil conditions. Due to the greater mobility of animals, the very idea of biomes refer more strongly to the vegetation present in the area than to the animal world. In contrast to "natural" biomes, urban ones are characterized by one particular special feature. Regardless of its geographical location conditioning climate and soil parameters, their main determinant is the occurrence of characteristic elements of the abiotic, anthropogenic environment (the city as a built structure) and man as the dominant species. The next step on the way to the emergence of a new idea of the city was to separate others, apart from the human species from among those inhabiting the city. Due to the possibility of feeling emotions, feelings and the very biology of life processes that are closest to humans, in the first step animals were selected as co-users of urbanized areas.

The role of animals in the modern city has been grounded through a series of changes and transformations that took place in a non-architectural environment. One of the most important, if not the most important, elements were changes in the approach towards animals at the philosophical and ethical level. First and foremost, the concept was connected with the evolution of views regarding perception of the role of animals to humans as sentient and thinking beings [3]. The reasons for evolution of the idea from complete objectification of animals to humanitarian attitudes, and their philosophical and social foundations date back to the end of the 18th century, while their development was followed by technical inventions and discoveries made from the mid-nineteenth century. However, it was the age of Enlightenment, the loosening of religious morality, that brought the first resolutions banning abuse of animals, finally confirmed by the theory of evolution by Charles Darwin and his work "On the Origin of Man" from 1871 [4]. Albert Schweitzer later transferred this idea into philosophical ground, creating the basis of "ethics in the worship of life", equating the right to live and the lack of suffering of every living organism [5].

Views on animal rights to decent conditions of life without hunger and suffering became evident in contemporary public debate following the publication by the Australian philosopher Peter Singer book "Animal Liberation" in 1975 [6] and four years later the ethics manual entitled "Practical Ethics" [7], discussing more broadly the aforementioned issues. A critical reference to the doctrine of species chauvinism, established in turn by ancient philosophical thought, foundations of Christian religiosity and the need for material human domination, underlies the construction and popularization of thoughts about the ethics of dealing with animals. It also gave an ideological basis for creating the Animal Liberation Movement. 


\section{The concept of zoopolis versus zoopolia}

The direct connection between the idea of city created by people (polis) and the animal world (zoo) was a long-lasting, multi-faceted process of broadening the meaning of animal subjectivity in culture, art and politics. The very concept of zoopolis [8] was initially applied to political science, in the context of spaces shared by man and domestic animals, where the city was defined as a political community of its inhabitants, and derived from the latter for over a decade term zoopolia created in relation to the build environment by Jennifer Wolch [9].

Zoopolia [10] is a version of urban space created as an alternative, but at the same time complementary to the idea of metropolis, but intended for both people and animals, and more broadly - nature. Due to the fact that areas occupied by wild nature disappear not only in the urbanized areas, but also outside its zones, maintaining the traditional form of the city will result in a significant deprivation of the environment of human life and nature as a whole [11]. This definition is based on a newly formulated design principle called nonanthropocentric design.

The presence of animals in cities is becoming more and more an important factor for maintaining balance in an artificially created environment, which slowly is becoming the only environment of human life. We are dealing here with issues related to both the presence of wild animals, domesticated ones, but also with the need to farm livestock inside the city. Although this is not the mainstream of changes, the confusion of both of these groups will in future generate further spatial conflicts in the field of meeting the needs of each of them.

The definition of zoopolis refers simultaneously to the way of perceiving wild animals in contemporary urban structures as a binding element for maintaining a close relationship between human beings and animals in places transformed by the presence of people. The aforementioned zoogeography in this case gives a scientific background for the analysis of activities in urban space based on the so-called cultural geography of animals, related to the domestication of animals and on humanistic geography and social sciences. On the other hand, we are dealing with the presence of a newly developing field of knowledge, with no scientific basis for discussions on the role of wild animals in urban space, or even the phenomenon of crowding out the presence of wild nature in urban research according to the notion that urbanized areas are the exclusive domain of man.

Sharing space by people and animals has become the first of the functional development possibilities by extending the user group to their "non-urban" wilderness zone.

This will apply to phenomena such as rewilding ${ }^{\dagger}[14]$, in the case of urbanized spaces leaving fragments of land in close relation to urbanized structures inhabited by man in an open form, intended for targeted re-naturalization, "savage landscape" often natural from an ethical point of view.

It will apply to both planar areas and point locations inside cities. Areas such as the Oostvardensplassen reserve between Almere and Lelystad, reported as the first and most comprehensive example of such activities, whether Richmond Park in London, the Wandle River area in London [15] or the Welsh Cambrian Wildwood [16] proves the culture-creating potential of wilderness habitat areas in cities.

The process that is currently underway, both supported by human activities and spontaneous, has been called the enchantment of the city [11]. Although this concept appeared in works of Wolch influenced by the philosophy of animal rights/ philosophy of

\footnotetext{
$\dagger$ English term rewilding is the process of restoring the area to its natural state, the last stage of which is a completely natural land [12]. This process takes place through the use of natural phenomena that aim to create sustainable systems. In Poland, it also functions as a term for land re-savagery, although this term is used to a much lesser extent [13].
} 
animal liberation [17] or more broadly, eco philosophy, it is based on a form of reversed determinism which is to compensate for the past injustices and harms caused to animals by humans, denying them the right to life without suffering. Therefore, the beneficiaries of the city of philosophical, sociological and artistic research in the form of zoepolis, for the first time as the motto of the exhibition "Zoepolis. Design for plants and animals." for ideological unity between humans and other living beings (both from the world of animals and plants), sometimes more often become evident in the form of artistic performances entering the realm of arts, as mentioned earlier. However, the aforementioned exhibition has become a contribution to taking a step further. It enabled the definition of a new, ideological concept concerning the space in which the implication of this art occurs - zoepolis, as a juxtaposition of the ideological concept of zoe [18], derived directly from the field of philosophy, the definition of vitality, naked life - features common to all living creatures and polis as cities, giving in this way, according to the authors of definition - Monika Rosińska and Agata Szydłowska - a more non-anthropocentric approach towards design, in which both animals and plants become main subjects of creative activities.

The issue of creating a world for people and animals in its architectural dimension was taken for the first time in the work of Maciej Siuda "New Technical Conditions" consisting of a drawing and a written work constituting an extension and transformation of "Technical conditions that should be met by buildings and their location"- the most important legal act in Poland regarding the principles of architectural design. Especially the written part is a literary answer to the need of taking into account the presence and welfare of non-human species in the architectural space created by man. At the same time, however, it is only a literary connection, referring to enlargement, in the form of additions, a currently binding legal act, and not a real attempt to change the way of defining the architectural world in a holistic context. Therefore, despite the untypical form, this work should be defined more as an occurrence, than a real solution to a specific social problem. The graphic part itself illustrates the proposal of implementation of the proposed transformations of legal provisions, a vision of the space designed basing on the "New Technical Conditions", in which proposed solutions adjusting the space for animals and plants fully interact with the "human" space, creating the beginning of a new, compact city.

The city of animals - zoopolis has become the idea that led to the consolidation of the notion of non-anthropocentric design in the architectural dimension. While the "city for animals" is a utopia, the inclusion of elements of thinking about the space available not only for humans, but also for other species that, as connected with environmental changes caused by humans, reside in the vicinity of their habitat, becomes nowadays necessary for maintaining balance in the urban environment.

The concept that most strongly influenced the development of the idea of nonanthropocentric architecture was created as part of artistic activities of the Ant Farm group. Combining the search for solutions that allow the coexistence of people and animals in, most often artificially created or dissected, environment, situated in an increasingly important context of ubiquitous media and increasing importance of mobility, have become the main premises in the design activities undertaken by the group. Developed from 1968 to

\footnotetext{
\$ Exhibition "Zoepolis. Design for plants and animals, an exhibition on non-anthropocentric design "in the Dizajn BWA gallery in Wrocław was co-financed under the program of the Ministry of Science and Higher Education under the name" National Program for Humanities Development "in the years 20162019 and is a part of the project "Cartography of Strangeness, Otherness and e(x)clusion. Perspective of philosophy and contemporary art "under the supervision of dr hab. Magdalena Sroda. The exhibition, which took place on 17/11/2017 - 14/01/2018, was mainly based on a collection of contemporary designs by Fontarte, Małgorzata Gurowska, Karolina Kotowska and Lukasz Kowalski, Florist Graphics, Bartosz Mucha, Nenukko, Alicja Patanowska, Maciej Siuda and Michał Szot, curator's care of Monika Rosińska and Agata Szydłowska.
} 
the version recorded in 1973, the idea of Dolphin Embassy - a utopian vision of the habitat, placed in a hermetic environment somewhere in the open sea, described a number of theoretical issues relevant to creating a relationship between species in the environment prepared for this purpose. This work encompassed a number of issues of architectural design enabling the conscious interaction between people in the terrestrial habitat and animals in the marine habitat. It concerned the nascent idea of zoopolitics at the time, as a tool for regulating principles of coexistence within not only one species (human), but within the whole animal world, of which man is only one of the elements. The embassy itself, in its physical layer, was supposed to be a hybrid space, connecting the terrestrial environment with water, constituting a self-sufficient place of life and work, a network of laboratories investigating interspecies relations [19].

This and many other similar ideas show the vision of a modern city, which can no longer function in the present form, but in the form needed by the world that has not yet occurred. In a non-anthropocentric or better - zoo-centric approach, the focus will be on the fulfillment of life needs of all animals living in cities, including humans, and urbanized space will be a set of parallel worlds in which both people and nature live in the same area, occupying layers which only sometimes cross or overlap.

\section{The determinants of the transformation process of modern polis}

Before moving on to the values that characterize a non-anthropocentric city - contemporary zoopolis transforming itself in order to improve the living conditions of people, animals and the general state of urban environment, regardless of the reasons for these transformations, it is necessary to define the main directions of changes taking place in contemporary polis urbanized areas of Western civilization. This will allow for the identification of trends that enable or counteract creating structures with the ability of adapting to contemporary trends. These determinants were divided into subgroups referring to the functionality of the city, the importance of greenery, the transformation of borders of urbanized areas and the emerging multi-dimensional structure of the city.

Table 1. Modern polis - the transformation determinants.

\begin{tabular}{|l|l|}
\hline \multicolumn{1}{|c|}{ Category } & \multicolumn{1}{c|}{ Attribute } \\
\hline \multirow{5}{*}{ Function } & $\begin{array}{l}\text { more uniform than ever before distribution of functions in the city } \\
\text { structure in its physical, not administrative, borders; }\end{array}$ \\
\cline { 2 - 3 } & departure from the city zoning paradigm; \\
\cline { 2 - 3 } & fragmentation of functions for their easier access; \\
\cline { 2 - 3 } Greenery & alienation of large single-function areas; \\
\cline { 2 - 3 } & $\begin{array}{l}\text { liquidation of socially or natural disruptive functions, or their considerable } \\
\text { fragmentation; }\end{array}$ \\
\cline { 2 - 3 } & $\begin{array}{l}\text { creating internal connectors, buffer zones from functions previously treated } \\
\text { as peripheral; }\end{array}$ \\
\hline \multirow{4}{*}{ Composition } & consolidation of structures of urban greenery - linear, point or planar; \\
\cline { 2 - 2 } & fragmentation of components; \\
\cline { 2 - 2 } & temporality of elements of the composition; \\
\hline & blurring of boundaries of urbanized areas; \\
\cline { 2 - 2 } & $\begin{array}{l}\text { introduction of elements of multifaceted structures in the city - physical, } \\
\text { virtual, elevated and underground; }\end{array}$ \\
\hline
\end{tabular}




\section{Features of a non-anthropocentric city as a place of creating new functions and urban forms}

The basic change between traditional city and contemporary zoopolis determines its constitution, both legal and moral, resulting from the change in the human worldview and adopted by it, through the acquisition of education, ethical principles, the presence of wild animals in cities as a permanent and indispensable part of urban biome. The emergence of functions so far defined as non-urban or rural is in non-anthropocentric cities a method for supplementing functional deficiencies resulting from the characteristic structure of a historical city that cannot adapt to the scale of urbanization that we encounter nowadays. Too much remoteness of life and living places from elements functionally related to food production, maintaining biological balance of the urban environment, or allowing the maintenance of mental and cultural connectivity with nature at urban systems with compact structure, caused structural fragmentation and departure from the comprehensive functional zonation of contemporary cities. Breaking urban structure from the one with a single center to a polycentric system is already becoming necessary due to the increasing distance from functions condensed in the centers.

Zoopolis is a multifaceted city, functioning partly independently, and partially sharing areas designated for the purpose of different species. In this way, a patchwork, mixed structure is created. It causes specific forms of landscape, approaching the system of fragmented settlements connected by a naturally diverse open environment - with or without an additional utilitarian urban function.

In this context, in zoopolis - like cities there is a significant increase in the importance of ecological corridors in forming the continuous, linear-point structures of urban greenery. Designing urban greenery is therefore aimed not only at its recreational character within the immediate human neighborhood. Its role as an element of safe environment of animal life in this system with a continuous structure is fundamentally important for ensuring the safety of both animals and humans. The consequence of this is an increase in the level of biodiversity of human habitats by the appearance of much larger numbers of non-human species.

Separation of points, which are elements jointly used by people and animals, cause changes in the aesthetics of the newly created architecture. The very role of architecture is also subject to changes as a creation intended and adapted to the parameters of not only one species (humans). The growing complexity of created structures in this case is dictated by the necessity of expanding knowledge about the spatial needs of non-human users, which will result in the integration of large-scale architectural forms used by humans and elements currently classified as so-called small architecture, and ultimately intended for animals.

\section{Summary}

So far, all the proposals made to create a place of coexistence between people and animals show a vision of symbiosis possible only in the case of an ideal environment. In a hermetic space in which, with the greatest possible limitation of the influence of external stimuli, it will be possible to create a relationship devoid of aggression. Artificial creation of the urban space parameters, where, despite everything, man dominates, causes that in any case he remains the main recipient of space. Present only there, and in the scope defined by man, animals can participate in the functioning of architecture regardless of whether it is an implemented or utopian architecture. 


\section{References}

1. United Nations, Department of Economic and Social Affairs, Population Division, World Urbanization Prospects: The 2014 Revision, (ST/ESA/SER.A/366), 7 (2015)

2. L. Zimowski, Lokacje, siedliska, domy - ogrody w modelach transurbacji, rewitalizacji, teorii biomów, Zeszyty Naukowe Politechniki Poznańskiej, 592 (1990)

3. J. Kleszcz, Wpływ zwierząt na formę współczesnych przestrzeni miejskich, Kultura i Wartości, 9, 67-82 (2014)

4. K. Darwin, O pochodzeniu człowieka, 161-162 (1928)

5. A. Schweitzer, Z mojego życia..., 54 (1981)

6. P. Singer, Wyzwolenie zwierzat (2004)

7. P. Singer, Practical Ethics, Cambridge University Press (1993)

8. S. Donaldson, W. Kymlicka, Zoopolis. A Political Theory of Animal Rights, 156-157 (2011)

9. J. Wolch, Anima Urbis, Architectural Theories of the Environment: Posthuman Territory, 233 (2013)

10. J. Wolch, M. Owens, Animals in Contemporary Architecture and Design, Humanimalia: a journal of human/animal interface studies, 1-26 (2017)

11. R. Louv, Ostatnie dziecko lasu, 580-582, 277-284 (2016)

12. LIFE Przyroda, Wytyczne dla Wnioskodawców 2016. LIFE Przyroda i różnorodność biologiczna, 23, (2016), https://www.google.pl/url?sa=t\&rct=j\&q=\&esrc=s\&source= web\&cd $=5 \& v e d=0$ ahUKEwjC37TfmMvZAhXC8ywKHXF - AtUQFghFMAQ\&url= https\%3A\%2F\%2Fwww.nfosigw.gov.pl\%2Fdownload\%2Fgfx\%2Fnfosigw\%2Fpl\%2F nfoaktualnosci\%2F $113 \% 2 \mathrm{~F} 245 \% 2 \mathrm{~F} 1 \% 2 \mathrm{Fwytyczne}$ dla_wnioskodawcow2016_przyro da.pdf

13. D. Foreman, Instytut Ponownego Zdziczenia (The Rewilding Institute). Dzikie Życie, 10, 124 (2004)

14. G. Monbiot, Feral. Rewilding the Land, the Sea, and Human Life (2014)

15. Rewilding Britain, The River Wandle. A fantastic local rewilding project restoring life to a river in the heart of urban London (n.d.), http://www.rewildingbritain.org.uk/ rewilding/what - does - rewilding - look -like/rewilding -projects/the - river - wandle

16. Rewilding Britain, Cambrian Wildwood. The ambitious rewilding project in Wales wants wild ecosystems to thrive with people (n.d.), http://www.rewildingbritain.org.uk/ rewilding/rewilding - projects/cambrian -wildwood

17. T. Regan, The case of animal rights (1985)

18. B. Mroczkowski, Zoe. Wieczny obieg życia. Inspiracje w filozofii i popkulturze, Antyk $i$ współczesność. Recepcja filozofii starożytnej w myśli współczesnej. Od czasów Nietzschego do początków XX wieku, 241-262 (2015)

19. A. Taylor - Hochberg, Screen/Print \#7: Horizonte, Architect. Features (2014), https://archinect.com/features/article/93011262/screen -print - 7 - horizonte 